\title{
Effect of Mechanical, Cultural and Chemical Weed Control on Yield and Yield Components of Pigeonpeas, Cajanus cajan (L.) Millsp.'
}

\author{
R. Abrams and F. J. Juliá ${ }^{2}$
}

\section{INTRODUCTION}

Farm value of pigeonpeas, Cajanus cajan (L.) Millsp., has increased steadily during the last decade but total production in Puerto Rico decreased during the same period. One of the major reasons for this decline in production has been attributed to high-production costs. Thus a pigeonpea management system resulting in high yields and reduced production costs would make this crop competitive with other crops at current yield levels in the low lands of Puerto Rico.

Previous work showed that a combination of high plant populations and narrow spacing between rows significantly increased pigeonpea yields. ${ }^{3}$ Narrow row spacing alone also resulted in increased pigeonpea production but the plants produced fewer pods without affecting plant height, seed weight or protein content of the peas. The same combination affords an opportunity for controlling weeds more effectively. The following experiment was designed to determine the effect of weed control by mechanical, cultural and chemical means on yield and yield components of pigeonpeas.

\section{MATERIALS AND METHODS}

The field work was conducted in 1972 on a Coto clay at the Isabela Agricultural Experiment Station, Isabela, P.R. with two pigeonpea types; i.e., determinate and indeterminate cultivar and lines. Kaki, experimental lines 7, 12 and 142-A represented the indeterminate group; experimental lines $8 \mathrm{AB}-2,8 \mathrm{AB}-7,16 \mathrm{~A}$, and 21-B represented the determinate.

The experimental design was a split-plot with four replications. The main plots consisted of pigeonpea types of each flowering group. Four different weed control treatments were applied in the sub-plots: 1 , Check, no weed control; 2 , hand weeding as necessary; 3 , mechanical cultivation with a tractor; and 4, pre- and post-emergence chemical weed control. Prometryne

${ }^{1}$ Manuscript submitted to Editorial Board May 16, 1973.

2 Plant Breeder and Assistant Agronomist, respectively, Isabela Substation, Agricultural Experiment Station, College of Agricultural Sciences, Mayagüez Campus, University of Puerto Rico.

${ }^{3}$ Abrams, R. and Julia, F. J. Effect of planting time, plant population and row spacing on yield and other characteristics of pigeonpeas, Cajanus cajan (L.) Millsp., J. Agr. Univ. P.R. 57 (4) : 275-85, 1973. 
was applied as a pre-emergent herbicide at the rate of $3.3 \mathrm{~kg} / \mathrm{ha}$ and Paraquat as a post-emergent at the rate of $1.18 \mathrm{liter} / \mathrm{ha}$, when plants were about $45 \mathrm{~cm}$ tall.

For the indeterminate group the planting distance was $121.9 \mathrm{~cm}$ between rows and $20.3 \mathrm{~cm}$ between plants, and for the determinate lines $91.4 \mathrm{~cm}$ between rows and $30.5 \mathrm{~cm}$ between plants in a row. Each sub-plot consisted of four rows, $6.096 \mathrm{~m}$ long. Data were taken from the two inner rows. Spacing between plants was established by seeding heavily and then thinning to the desired within-row spacing, when seedlings were about 10 cm tall.

Pigeonpea yield in $\mathrm{ql}^{4} / \mathrm{ha}$ were taken on a mature green-pod basis. Plant height in $\mathrm{cm}$ was the average of six measurements per plot from ground level to the top of the plants. Date of flowering was the total number of days from planting until $\mathbf{5 0}$ percent of the plants in a plot were in bloom. The number of pods per plant and seeds per pod, and the weight in grams of 100 seeds are the averages of the measurements taken in five plants per plot. Variance of each character was analyzed and the means subjected to Duncan's New Multiple Range Test.

\section{RESULTS AND DISCUSSION}

\section{EFFECT ON INDETERMINATE TYPES OF PIGEONPEAS}

\section{Yield}

The average yield of indeterminate type pigeonpeas harvested as green pods from each of the weed-control treatments are shown in table 1, a. The analysis of variance disclosed no significant difference in yield between Kaki and the experimental lines. Lines 7, 12, and 142-A had been selected and tested during the last 4 years as high-yielders, equal to or better than the standard variety Kaki. Therefore, little or no difference in yield was expected between them. These same cultivar and experimental lines, however, responded significantly to the different weed-control treatments applied in this study. The control of weeds by chemical means increased the average green pod yield by $33.9,25.7$, and $21.7 \mathrm{ql} / \mathrm{ha}$ over the check, the mechanical and the hoe weed treatment, respectively.

\section{Plant Height}

There was no influence on the height of pigeonpea plants as a result of the different types of weed-control. Mean plant heights were 198.1, 198.1, 195.1 , and $192.0 \mathrm{~cm}$ for the chemical, hand, mechanical, and the no-weed control check, respectively (table $1, \mathrm{~b}$ ).

$$
\text { A quintal }=100 \mathrm{~kg} \text {. }
$$


TABLE 1.-Mean values for green pod yield, plant height, number of days to flower, and components of yield in four indeterminate pigeonpea cultivars: $a$, mean green pod yield in $q l / h a ; b$, mean plant height in $\mathrm{cm} ; c$, mean number of days to flower; $d$, mean number of pods per plant; $e$, mean 100-seed weight in $g$; and $j$, mean number of seeds per pod

\begin{tabular}{llllll}
\hline & \multicolumn{4}{c}{ Weed control } & \\
\cline { 2 - 5 } & None & Manual & Mechanical & Herbicide & Average \\
\hline
\end{tabular}

a. Mean green pod yield in $q l / h a^{1}$

\begin{tabular}{lccccc}
\hline Kaki & $103.9 \mathrm{~A}$ & $108.2 \mathrm{~A}$ & $97.9 \mathrm{~A}$ & $110.0 \mathrm{~A}$ & $104.6 \mathrm{~A}$ \\
Line 7 & $107.9 \mathrm{AB}$ & $94.5 \mathrm{~B}$ & $114.7 \mathrm{AB}$ & $130.1 \mathrm{~A}$ & $108.2 \mathrm{~A}$ \\
Line 12 & $83.2 \mathrm{C}$ & $115.2 \mathrm{AB}$ & $92.1 \mathrm{~B}$ & $135.6 \mathrm{~A}$ & $106.4 \mathrm{~A}$ \\
Line 142-A & $90.3 \mathrm{~B}$ & $106.9 \mathrm{AB}$ & $104.6 \mathrm{AB}$ & $126.8 \mathrm{~A}$ & $107.0 \mathrm{~A}$ \\
& & & & & \\
Average & $93.9 \mathrm{~b}$ & $106.1 \mathrm{~b}$ & $102.1 \mathrm{~b}$ & $127.8 \mathrm{a}$ & \\
\hline
\end{tabular}

b. Mean plant height in $\mathrm{cm}$

\begin{tabular}{lccccc}
\hline Kaki & $185.9 \mathrm{~B}$ & $195.1 \mathrm{AB}$ & $198.1 \mathrm{AB}$ & $204.2 \mathrm{~A}$ & $195.1 \mathrm{~B}$ \\
Line 7 & $182.9 \mathrm{~A}$ & $185.9 \mathrm{~A}$ & $182.9 \mathrm{~A}$ & $185.9 \mathrm{~A}$ & $182.9 \mathrm{~B}$ \\
Line 12 & $185.1 \mathrm{~A}$ & $198.1 \mathrm{~A}$ & $195.1 \mathrm{~A}$ & $198.1 \mathrm{~A}$ & $195.1 \mathrm{~B}$ \\
Line 142-A & $204.2 \mathrm{~A}$ & $207.3 \mathrm{~A}$ & $207.3 \mathrm{~A}$ & $207.3 \mathrm{~A}$ & $207.3 \mathrm{~A}$ \\
Average & $192.0 \mathrm{a}$ & $198.1 \mathrm{a}$ & $195.1 \mathrm{a}$ & $198.1 \mathrm{a}$ & \\
\hline \multicolumn{5}{c}{ c. Mean number of days to flower } \\
\hline Kaki & $152 \mathrm{~A}$ & $150 \mathrm{~A}$ & $150 \mathrm{~A}$ & $148 \mathrm{~A}$ & $150 \mathrm{~A}$ \\
Line 7 & $150 \mathrm{~A}$ & $150 \mathrm{~A}$ & $150 \mathrm{~A}$ & $150 \mathrm{~A}$ & $150 \mathrm{~A}$ \\
Line 12 & $151 \mathrm{~A}$ & $150 \mathrm{~A}$ & $149 \mathrm{~A}$ & $150 \mathrm{~A}$ & $150 \mathrm{~A}$ \\
Line 142-A & $150 \mathrm{~A}$ & $150 \mathrm{~A}$ & $150 \mathrm{~A}$ & $150 \mathrm{~A}$ & $150 \mathrm{~A}$ \\
Average & $150 \mathrm{a}$ & $150 \mathrm{~A}$ & $150 \mathrm{a}$ & $150 \mathrm{a}$ & \\
\hline
\end{tabular}

d. Mean number of pods per plant

\begin{tabular}{llllll}
\hline Kaki & $138.0 \mathrm{~A}$ & $147.0 \mathrm{~A}$ & $142.5 \mathrm{~A}$ & $142.5 \mathrm{~A}$ & $142.5 \mathrm{~A}$ \\
Line 7 & $136.5 \mathrm{~A}$ & $138.0 \mathrm{~A}$ & $141.0 \mathrm{~A}$ & $151.5 \mathrm{~A}$ & $141.8 \mathrm{~A}$ \\
Line 12 & $135.0 \mathrm{~A}$ & $153.0 \mathrm{~A}$ & $156.0 \mathrm{~A}$ & $157.5 \mathrm{~A}$ & $150.4 \mathrm{~A}$ \\
Line 142-A & $136.5 \mathrm{~A}$ & $145.5 \mathrm{~A}$ & $142.5 \mathrm{~A}$ & $141.0 \mathrm{~A}$ & $141.4 \mathrm{~A}$ \\
Average & $136.5 \mathrm{~b}$ & $145.8 \mathrm{ab}$ & $145.5 \mathrm{ab}$ & $148.0 \mathrm{a}$ & \\
\hline
\end{tabular}

e. Mean 100-seed weight in grams

\begin{tabular}{|c|c|c|c|c|c|}
\hline $\begin{array}{l}\text { Kaki } \\
\text { Line 7 } \\
\text { Line 12 } \\
\text { Line 142-A }\end{array}$ & $\begin{array}{l}34.8 \mathrm{~A} \\
29.3 \mathrm{~A} \\
29.9 \mathrm{~A} \\
30.0 \mathrm{~A}\end{array}$ & $\begin{array}{l}43.2 \mathrm{~A} \\
29.4 \mathrm{~A} \\
29.7 \mathrm{~A} \\
30.5 \mathrm{~A}\end{array}$ & $\begin{array}{l}36.0 \mathrm{~A} \\
28.8 \mathrm{~A} \\
29.0 \mathrm{~A} \\
29.6 \mathrm{~A}\end{array}$ & $\begin{array}{l}35.6 \mathrm{~A} \\
27.3 \mathrm{~A} \\
29.8 \mathrm{~A} \\
30.1 \mathrm{~A}\end{array}$ & $\begin{array}{l}35.2 \mathrm{~A} \\
28.7 \mathrm{D} \\
29.6 \mathrm{C} \\
30.0 \mathrm{~B}\end{array}$ \\
\hline Average & $31.0 \mathrm{a}$ & $30.9 \mathrm{a}$ & $30.9 \mathrm{a}$ & $30.7 \mathrm{a}$ & \\
\hline
\end{tabular}


TABle 1.-Continued

\begin{tabular}{lccccc}
\hline & \multicolumn{5}{c}{ Weed control } \\
\cline { 2 - 6 } & None & Manual & Mechanical & Herbicide & Average \\
\hline \multicolumn{5}{c}{$f$. Mean } \\
& number of seeds per pod \\
\hline Kaki & $3.2 \mathrm{~A}$ & $3.2 \mathrm{~A}$ & $2.8 \mathrm{~A}$ & $3.6 \mathrm{~A}$ & $3.2 \mathrm{~A}$ \\
Line 7 & $3.7 \mathrm{~A}$ & $3.5 \mathrm{~A}$ & $4.2 \mathrm{~A}$ & $3.6 \mathrm{~A}$ & $3.8 \mathrm{~A}$ \\
Line 12 & $3.1 \mathrm{~A}$ & $3.8 \mathrm{~A}$ & $3.1 \mathrm{~A}$ & $3.6 \mathrm{~A}$ & $3.4 \mathrm{~A}$ \\
Line 142-A & $3.5 \mathrm{~A}$ & $3.6 \mathrm{~A}$ & $3.8 \mathrm{~A}$ & $3.7 \mathrm{~A}$ & $3.7 \mathrm{~A}$ \\
Average & $3.4 \mathrm{a}$ & $3.5 \mathrm{a}$ & $3.5 \mathrm{a}$ & $3.6 \mathrm{a}$ & \\
\hline
\end{tabular}

1 Means not followed by the same letter are significantly different at the $P=$ 0.05 level as measured by Duncan's Multiple Range Test. Upper case letters indicate differences between cultivars and between weed control treatments in same cultivar. Lower case letters indicate differences between weed control practices.

Line 142-A, a tall-growing one, differed significantly in total plant height as compared with Kaki and Lines 7, and 12.

\section{Number of Days to Flower}

None of the weed control treatments significantly affected the number of days to flower. Studies by Morales and Abrams ${ }^{5}$ indicated this character is determined by one or two genes and the heritability value for it above 90 percent. All these indeterminate lines, the commercial cultivar Kaki for instance. have been selected on a maturity basis as they tend to flower at about the same time, i.e., 150 days from planting date (table 1, c).

\section{Number of Pods per Plant}

All weed control treatments significantly increased the number of pods per plant with respect to the no weed control. The mean number of pods for chemical, hand, mechanical and the check were 148.0, 145.8, 145.5, and 136.5 , respectively (table $1, \mathrm{~d}$ ).

\section{Weight of 100 Seeds}

Commercial cultivar Kaki and the experimental lines under study differed significantly in seed weight. Kaki showed the greatest weight per 100 seeds, $35.2 \mathrm{~g}$, followed by Line 142-A with 30.0 , Line 12 with 29.6, and Line 7 with 28.7 (table 1, e). Seed size was not affected by the weed control treatments. This characteristic has a high heritability value, as in the case of

${ }^{5}$ Morales, A., and Abrams, R., Inheritance of some quantitative characters in pigeonpeas (Cajanus cajan (L.) Millsp.) J. Agr. Univ. P.R. 55(1) : 23-43, 1971. 
TABLE 2.-Mean values for green pod yield, plant height, number of days to flower, and components of yield in four determinale pigeonpea cultivars: a, mean green pod yield in $q l / h a ; b$, mean plant height in $\mathrm{cm} ; c$, mean number of days to flower; $d$, mean number of pods per plant; $e$, mean 100 seed weight in grams; and $f$, mean number of seeds per pod

\begin{tabular}{cccccc}
\hline \multicolumn{6}{c}{ Weed control } \\
\cline { 2 - 5 } & None & Manual & Mechanical & Herbicide & . Average \\
\hline
\end{tabular}

a. Mean green pod yield in $q l / h a^{1}$

\begin{tabular}{llllll}
\hline Line 8 AB-2 & $35.4 \mathrm{~B}$ & $45.1 \mathrm{~A}$ & $46.4 \mathrm{~A}$ & $44.4 \mathrm{~A}$ & $42.7 \mathrm{~B}$ \\
Line 8 AB-7 & $28.9 \mathrm{~B}$ & $30.5 \mathrm{~B}$ & $32.1 \mathrm{~B}$ & $39.4 \mathrm{~A}$ & $32.9 \mathrm{C}$ \\
Line 16 A & $36.6 \mathrm{~B}$ & $41.0 \mathrm{~A}$ & $46.4 \mathrm{~A}$ & $39.4 \mathrm{AB}$ & $40.6 \mathrm{~B}$ \\
Line 21 B & $59.4 \mathrm{~B}$ & $55.7 \mathrm{AB}$ & $56.9 \mathrm{AB}$ & $63.8 \mathrm{~A}$ & $58.9 \mathrm{~A}$ \\
& & & & & \\
Average & $39.9 \mathrm{~b}$ & $43.1 \mathrm{ab}$ & $45.6 \mathrm{ab}$ & $46.7 \mathrm{a}$ & \\
\hline
\end{tabular}

b. Mean plant height in $\mathrm{cm}$

\begin{tabular}{llllll}
\hline Line 8 AB-2 & $182.9 \mathrm{~A}$ & $179.8 \mathrm{~A}$ & $176.8 \mathrm{~A}$ & $188.9 \mathrm{~A}$ & $182.9 \mathrm{~A}$ \\
Line 8 AB-7 & $173.7 \mathrm{~A}$ & $173.7 \mathrm{~A}$ & $176.8 \mathrm{~A}$ & $170.7 \mathrm{~A}$ & $173.7 \mathrm{~B}$ \\
Line 16 A & $173.7 \mathrm{~A}$ & $176.8 \mathrm{~A}$ & $170.7 \mathrm{~A}$ & $167.6 \mathrm{~A}$ & $170.7 \mathrm{~B}$ \\
Line 21 B & $182.9 \mathrm{~A}$ & $188.9 \mathrm{~A}$ & $182.9 \mathrm{~A}$ & $176.8 \mathrm{~A}$ & $182.9 \mathrm{~A}$ \\
Average & $176.8 \mathrm{a}$ & $179.8 \mathrm{a}$ & $176.8 \mathrm{a}$ & $176.8 \mathrm{a}$ & \\
\hline
\end{tabular}

c. Mean number of days to flower

\begin{tabular}{lllrll}
\hline Line 8 AB-2 & $141.7 \mathrm{~A}$ & $137.0 \mathrm{~A}$ & $141.7 \mathrm{~A}$ & $141.7 \mathrm{~A}$ & $140.5 \mathrm{~A}$ \\
Line 8 AB-7 & $137.0 \mathrm{~A}$ & $137.0 \mathrm{~A}$ & $137.0 \mathrm{~A}$ & $137.0 \mathrm{~A}$ & $137.0 \mathrm{AB}$ \\
Line 16 A & $124.0 \mathrm{~A}$ & $124.0 \mathrm{~A}$ & $27.2 \mathrm{~A}$ & $127.2 \mathrm{~A}$ & $125.6 \mathrm{C}$ \\
Line 21 B & $127.2 \mathrm{~A}$ & $124.0 \mathrm{~A}$ & $24.0 \mathrm{~A}$ & $124.0 \mathrm{~A}$ & $124.5 \mathrm{C}$ \\
Average & $132.5 \mathrm{a}$ & $130.5 \mathrm{a}$ & $132.5 \mathrm{a}$ & $132.5 \mathrm{a}$ & \\
\hline
\end{tabular}

d. Mean number of pods per plant

\begin{tabular}{llllll}
\hline Line 8 AB-2 & $33.0 \mathrm{~B}$ & $28.0 \mathrm{C}$ & $29.0 \mathrm{BC}$ & $45.0 \mathrm{~A}$ & $33.7 \mathrm{C}$ \\
Line 8 AB-7 & $31.5 \mathrm{~B}$ & $31.2 \mathrm{~B}$ & $32.0 \mathrm{~B}$ & $46.2 \mathrm{~A}$ & $35.2 \mathrm{~B}$ \\
Line 16 A & $36.0 \mathrm{~B}$ & $32.0 \mathrm{~B}$ & $33.5 \mathrm{~B}$ & $45.2 \mathrm{~A}$ & $36.7 \mathrm{~B}$ \\
Line 21 B & $36.0 \mathrm{~B}$ & $32.0 \mathrm{~B}$ & $36.2 \mathrm{~B}$ & $49.0 \mathrm{~A}$ & $46.4 \mathrm{~A}$ \\
Average & $33.7 \mathrm{c}$ & $35.2 \mathrm{bc}$ & $36.7 \mathrm{ab}$ & $38.3 \mathrm{a}$ & \\
\hline
\end{tabular}

e. Mean 100-seed weight in grams

\begin{tabular}{llllll}
\hline Line 8 AB-2 & $28.6 \mathrm{~A}$ & $29.5 \mathrm{~A}$ & $29.0 \mathrm{~A}$ & $28.2 \mathrm{~A}$ & $28.8 \mathrm{C}$ \\
Line 8 AB-7 & $30.8 \mathrm{~A}$ & $31.1 \mathrm{~A}$ & $31.8 \mathrm{~A}$ & $32.1 \mathrm{~A}$ & $31.5 \mathrm{~A}$ \\
Line 16 A & $30.8 \mathrm{~A}$ & $32.1 \mathrm{~A}$ & $31.5 \mathrm{~A}$ & $31.3 \mathrm{~A}$ & $31.4 \mathrm{~A}$ \\
Line 21 B & $31.1 \mathrm{~A}$ & $29.1 \mathrm{~A}$ & $30.1 \mathrm{~A}$ & $30.6 \mathrm{~A}$ & $30.4 \mathrm{~B}$ \\
Average & $30.3 \mathrm{a}$ & $30.6 \mathrm{a}$ & $30.6 \mathrm{a}$ & $30.6 \mathrm{a}$ & \\
\hline
\end{tabular}


TABLE 2.-Continued

\begin{tabular}{llllll}
\hline & \multicolumn{5}{c}{ Weed control } \\
\cline { 2 - 5 } & None & Manual & Mechanical & Herbicide & Average \\
\hline \multicolumn{5}{c}{ f. Mean number of seeds per pod } \\
\hline Line 8 AB-2 & $4.3 \mathrm{~A}$ & $3.8 \mathrm{~A}$ & $4.6 \mathrm{~A}$ & $4.7 \mathrm{~A}$ & $4.3 \mathrm{~A}$ \\
Line 8 AB-7 & $4.2 \mathrm{~A}$ & $3.9 \mathrm{~A}$ & $4.4 \mathrm{~A}$ & $4.4 \mathrm{~A}$ & $4.1 \mathrm{~A}$ \\
Line 16 A & $5.0 \mathrm{~A}$ & $4.9 \mathrm{~A}$ & $4.8 \mathrm{~A}$ & $4.6 \mathrm{~A}$ & $4.4 \mathrm{~A}$ \\
Line 21 B & $4.8 \mathrm{~A}$ & $4.2 \mathrm{~A}$ & $4.8 \mathrm{~A}$ & $5.0 \mathrm{~A}$ & $4.6 \mathrm{~A}$ \\
Average & $4.5 \mathrm{a}$ & $4.0 \mathrm{a}$ & $4.4 \mathrm{a}$ & $4.6 \mathrm{a}$ & \\
\hline
\end{tabular}

1 Means not followed by the same letter are significantly different at the $P=$ 0.05 level as measured by Duncan's Multiple Range Test. Upper case letters indicate difference between cultivars and between weed control treatments in same cultivar. Lower case letters indicate differences between weed control practices.

number of days to flower, and thus probably is not affected significantly in any of the pigeonpea lines by weed control.

Number of Seeds per Pod

This yield component was not affected by the various weed controI practices although those which were effective slightly increased this component (table 1, f). Lines 7, 142-A, 12, and Kaki cultivar had 3.8, 3.7, 3.4, and 3.2 seeds per pod, respectively, indicating that they were more or less uniform in this respect. Previous studies by Morales and $\mathrm{Abrams}^{6}$ show that there is very little genetic variation for this character among the commercial cultivars planted in Puerto Rico.

EFFECT ON DETERMINATE TYPE LINES

Results from determinate-type pigeonpea plot weed control experiments, for all the characters under investigation, followed a pattern very similar to those reported above for indeterminate-type plots. Chemical control was superior (table $2, a$ ).

It must be noted, however, that yield performance of determinate-type pigeonpeas at the population level employed in these experiments is about 50 percent of that obtained from indeterminate lines. This difference is due to a shorter vegetative cycle, a more compact plant with fewer branches, and with flowering at and production of pods only on terminal buds of the determinate-type lines included in these investigations. Thus, the difference in yield between determinate and indeterminate types of pigeonpeas can be partially compensated by using higher plant densities, the big ad-

${ }^{6}$ Ibid. 
vantage being that the determinate lines are short, compact plants, welladapted to mechanical harvesting.

The direct yield components of pigeonpeas are the number of pods per plant, number of seeds per pod, and seed weight. The results obtained with these components show a trend very similar to those observed in the indeterminate types. Lines 8 AB-2, 8 AB-7, 16-A and 21-B, however, differ significantly in their mean number of pods per plant and seed weight. These lines have not been screened as thoroughly as the indeterminate ones and evidently should differ widely in their yield performance, plant height and maturity as shown in table $2 \mathrm{a}, \mathrm{b}$, and c.

\section{SUMMARY}

Four determinate and four indeterminate types of pigeonpea cultivars and experimental lines were grown at the Isabela Agricultural Experiment Substation during 1971-72 to determine the effects of mechanical, cultural and chemical weed control practices on six characters affecting pigeonpea yield.

The chemical, mechanical and hand weed control treatments increased the green pod yield and the number of pods per plant, but had no effect on plant height, number of days to flower, seed weight, and number of seeds per pod. Greatest yield increase was obtained by weed control with chemicals.

\section{RESUMEN}

Para determinar hasta qué grado el control de los yerbajos mediante el cultivo mecanizado, el desyerbo a mano y la aplicación de herbicidas puedan influir en seis caracteres que afectan el rendimiento del gandur, se estableció un experimento con cuatro variedades de tipo determinado y cuatro de tipo indeterminado en la Subestación Experimental de Isabela en el año 1971-72.

Los mejores rendimientos se obtuvieron usando herbicidas preemergentes y posemergentes. Aunque el rendimiento y el número de vainas por planta aumentaron, ninguno de los tratamientos afectó la altura de las plantas, el número de días hasta la floración, el peso de la semilla y el número de granos por vaina. 